\title{
JERZY KONSTANTY CZARTORYSKI A KWESTIA WSPÓŁPRACY SŁOWIAN W MONARCHII HABSBURSKIEJ1
}

\section{Stanisław Pijaj}

http://orcid.org/0000-0002-2819-077X

Uniwersytet Jagielloński w Krakowie (Polska)

\section{ABSTRACT \\ JERZY KONSTANTY CZARTORYSKI AND THE PROBLEM OF SLAV COOPERATION IN THE HABSBURG MONARCHY}

Prince Jerzy Konstanty Czartoryski (1828-1912) was known both as a lover of music and theatre and a politician. He went into politics quite late, not until the second half of the 1860 s. It was then that he was given the nickname of "Federalist Prince". Jerzy Konstanty Czartoryski worked towards a closer cooperation between Poles and other Slavs in the Habsburg Monarchy, especially Czechs, and Ukrainians in Galicia. His endeavours in the 1870s were not particularly successful, but they earned him the position of a mediator between Poles and other Slavs in the Monarchy, which was frequently used in later years. The article identifies the sources of Jerzy Konstanty Czartoryski's interest in Slav issues and presents his actions to support political cooperation among Slavs in the Habsburg Monarchy in the second half of the $19^{\text {th }} \mathrm{c}$.

Keywords: Jerzy Konstanty Czartoryski, Habsburg Monarchy, Slavs, Poles, Galicia.

Słowa kluczowe: Jerzy Konstanty Czartoryski, monarcha habsburska, Słowianie, Polacy, Galicja.

Jerzy Konstanty Czartoryski był nietypową postacią na galicyjskiej scenie politycznej. Przylgnęło do niego miano „Książę Federalista”, nadane mu przez Kazimierza Chłędowskiego w końcu lat 60. XIX wieku². Sympatie federalistyczne Czar-

1 Artykuł powstał w ramach projektu OPUS 13, finansowanego przez Narodowe Centrum Nauki w Krakowie, pt. „Pomiędzy dwoma zjazdami w Pradze. Związki między Słowianami w Europie Środkowej i Południowo-Wschodniej w latach 1848-1908" (2017/25/B/HS3/00240).

2 Publikowane przez Kazimierza Chłędowskiego w „Kraju” w 1869 r. felietony dotyczące galicyjskich polityków, w tym Jerzego Konstantego Czartoryskiego, zostały wydane w 1951 r. przez Antoniego Knota, zob. K. Chłędowski, Album fotograficzne, oprac. i wyd. A. Knot, Wrocław 1951, s. 24-27. Jerzy Konstanty Czartoryski nie doczekał się, jak dotąd, biografii, jego biogram autorstwa S. Kieniewi- 
toryskiego podkreślali i inni współcześni mu autorzy charakteryzujący polityków polskich z Galicji, zwracano przy tym uwagę, że łączył on federalizm z liberalizmem, co było rzadkie 3 . Sam Czartoryski wielokrotnie tłumaczył swoje poglądy, choćby w opublikowanych w latach 1869 i 1871 broszurach Przed sejmem 1869 i Uwagi o polityce polskiej $w$ Austryi ${ }^{4}$. Trzecim elementem, który eksponowano, charakteryzując poglądy polityczne Czartoryskiego, były jego „sympatie słowiańskie” czy wręcz „skłonności słowianofilskie”5. Niewątpliwie Jerzy Konstanty Czartoryski należał do tych nie tak licznych polityków polskich w Galicji, którzy utrzymywali ożywione kontakty z politykami słowiańskimi w monarchii habsburskiej i zdecydowanie angażowali się na rzecz współpracy Słowian. W przeciwieństwie do wielu Polaków krytycznie oceniał politykę węgierską i wiązanie z nią polskich nadziei; nie ukrywał, że dla niego sojusz ze Słowianami jest „naturalniejszy niż z Niemcami”.

Sympatie słowiańskie Jerzego Konstantego Czartoryskiego tłumaczono najczęściej powiązaniami rodzinnymi, a konkretnie wpływem jego żony - Czeszki Marii Čermák ${ }^{7}$. Opinie te są z pewnością przesadzone, choć Maria Čermák rzeczywiście uchodziła za osobę energiczną, ambitną i mającą duży wpływ na męża. Podkreśla się jej liczne zasługi, a nawet można spotkać się z ocenami, że to żona uczyniła z księcia ,polskiego patriotę" "Żeniąc się z nią, Czartoryski popełnił mezalians, co ponoć zostało mu zapamiętane przez Franciszka Józefa i odbiło się na jego politycznej karierze?

Maria Čermák wywodziła się z rodziny mieszczańskiej, jej dziad - Josef Čermák (1767-1822), ojciec - Jan Nepomuk Čermák senior (1797-1843) i stryj - Josef Julius Čermák (1799-1851) byli lekarzami powiązanymi ze środowiskami akademickimi Pragi i Wiednia. Čermákowie należeli do elity praskiego mieszczaństwa, utrzymywali też kontakty z czołowymi czeskimi działaczami narodowymi. Tradycje rodzinne

cza znajduje się w Polskim stowniku biograficznym, zob. S. Kieniewicz, Jerzy Konstanty Czartoryski (1828-1912) [w:] Polski stownik biograficzny, t. 4, Kraków 1938, s. 278-279. Biogram ten został także opublikowany w pracy: Czartoryscy. Trzydzieści sześć życiorysów, Kraków 1938, s. 218-222. Ostatnio szerzej o Jerzym Konstantym Czartoryskim pisała Iwona Długoń, zob. eadem, Czartoryscy z Pełkiń. Dzieje rodziny, Rzeszów 2019 (mps pracy doktorskiej), s. 62-89.

3 Zob. np. [S. Koźmian], Reprezentacja kraju naszego w Radzie Państwa 1879, Kraków 1879, s. 30-31; [S. Rossowski] Monokl, Wizerunki sejmowe. Ludzie i sprawy. Przyczynek do historyi samorzadu galicyjskiego, Lwów 1903, s. 30-31; Fr.J., Wśród nowych ludzi, „Tygodnik Ilustrowany”, 10 II 1906, nr 5, s. 86; Ś.p. Jerzy ks. Czartoryski, „Czas”, 28 XII 1912, nr 597, s. $2-3$.

4 J. Czartoryski, Przed sejmem 1869, Lwów 1869; idem, Uwagi o polityce polskiej w Austryi, Lwów 1871.

5 [S. Rossowski] Monokl, op. cit., s. 30; Fr.J., op. cit., s. 86.

6 J. Czartoryski, Uwagi o polityce polskiej..., s. 60-61.

7 [S. Rossowski] Monokl, op. cit., s. 30; K. Chłędowski, Pamiętniki, przyg. do druku, wstęp i przyp. A. Knot, t. 1: Galicja (1843-1880), Wrocław 1951, s. 297; t. 2: Wiedeń (1881-1901), Wrocław 1951, s. 59.

8 M. Sapieżyna, My i nasze Siedliska, Kraków 2008, s. 52. Zob. też: Biblioteka XX. Czartoryskich w Krakowie (dalej: Czart.), rkps 7636 III: W. Dzie du szy cki, Wiązownica dom moich Dziadków (mps), s. 12; [S. Ros sow ski] Monokl, op. cit., s. 30; K. Chłędow ski, Pamiętniki, t. 1, s. 191, t. 2, s. 58-59.

9 M. Červinková-Riegrová, Zápisky. I (1880-1884), Praha 2009, s. 314-315. Zob. też: [F.L. Rieger], Př́spěvky k listáři Dra Frant. Lad. Riegra, díl 2, Praha 1924, s. 173. 
kontynuowali dwaj najstarsi bracia Marii, Josef i Jan Nepomuk junior, obydwaj zostali lekarzami i profesorami uniwersytetów ${ }^{10}$. Jerzy Konstanty Czartoryski był silnie związany z rodziną Marii, można jednak sądzić, że przede wszystkim z młodszymi spośród jej braci: Jaroslavem i Karelem. Czartoryskim był szczególnie bliski Jaroslav Čermák (1831-1878), postać z pewnością nietuzinkowa ${ }^{11}$. Zaliczany do najważniejszych czeskich malarzy XIX wieku, większość życia spędził za granicą, głównie we Francji, gdzie nawiązał liczne kontakty w środowiskach emigrantów politycznych, zapewne także z Polakami. Niewątpliwie można go określić jako słowianofila. Zainteresowanie Słowiańszczyzną znalazło odbicie nie tylko w jego twórczości, odbył także szereg podróży po krajach słowiańskich, przede wszystkim Słowiańszczyzny południowej. Szczególnie interesowała go Czarnogóra, którą odwiedził po raz pierwszy w 1858 roku, wracał tam w latach 1862-1865, gdy mieszkał w południowej Dalmacji. Uczestniczył także w walkach Czarnogórców z Turkami ${ }^{12}$. Najmłodszy z braci Marii, mieszkający w Wiedniu, Karel Čermák (zm. 1882) był wydawcą i księgarzem. O bliskich stosunkach z Czartoryskimi świadczy fakt, że został ojcem chrzestnym ich jedynego syna Witolda ${ }^{13}$. To on był wydawcą monografii wiedeńskiego aktora Karla Fichtnera napisanej przez Jerzego Konstantego Czartoryskiego ${ }^{14}$. Nakładem Karela Čermáka ukazało się także czeskie tłumaczenie pracy Juliana Klaczki Kongres moskiewski i panslawistyczna propaganda ostrzegającej przed rosyjskim panslawizmem i będącej krytyką polityków czeskich uczestniczących w zjeździe słowiańskim w Moskwie w 1867 roku. Niewątpliwie świadczy to o jego propolskiej postawie.

10 Bardziej jest znany młodszy z braci Čermáków, Jan Nepomuk Čermák junior (Johann Nepomuk Czermak) fizjolog, profesor uniwersytetów w Grazu, Krakowie, Peszcie i Lipsku, Starszy z braci Josef Čermák (Joseph Czermak) był psychiatrą, profesorem uniwersytetu w Grazu. Jan Nepomuk Čermák junior określany jest powszechnie jako uczony „niemiecko-austriacki”, można się także spotkać $\mathrm{z}$ opiniami, że obydwaj bracia $\mathrm{i}$ ich potomstwo zgermanizowało się. $\mathrm{Z}$ pewnością dotyczy to synów Josefa Čermáka: Wilhelm Čermák (Czermak) (1856-1906) - lekarz był profesorem na uniwersytecie w Innsbrucku i niemieckim uniwersytecie w Pradze, Paul Czermak (1857-1912) - fizyk był profesorem uniwersytetów w Grazu i Innsbrucku. Wnuk Josefa Čermáka, Wilhelm Czermak (1899-1953) egiptolog i afrykanista był profesorem uniwersytetu w Wiedniu. Biogramy większości z wymienionych można znaleźć w Österreichisches Biographisches Lexikon, bądź w innych słownikach i encyklopediach. W Österreichisches Biographisches Lexikon jest także biogram Jozefa Juliusa Čermáka (1799-1851) stryja Marii, lekarza, profesora uniwersytetów w Grazu i Wiedniu. Szerzej na temat rodziny Čermák zob. V. Černý, F.V. Mokrý, V. Náprstek, Život a dílo Jaroslava Čermáka, Praha 1930, s. 5-17; I. Dłu goń, op. cit., s. 71-73.

11 Czart., rkps 7636 III, s. 11; [S. Koźmian], op. cit., s. 30; V. Černý, F.V. Mokrý, V. Náprstek, op. cit., s. 41-43, 54-55, 168-173.

12 V. Černý, F.V. Mokrý, V. Náprstek, op. cit., s. 18-163; F. Šístek, Zpřitomněna minulost. Jaroslav Čermák: mezi slovanstvím a orientalismem [w:] F. Šístek, Junáci, horalé a lenoši. Obraz Černé Hory a Černohorců v české společnosti, 1830-2006, Praha 2011, s. 52-64; V. Žáček, S Jaroslavem Čermákem na Černé Hoře a v Albanii, „Slovanský přehled”, R. 68, 1982, č. 4, s. 345-352; T. Macan, Jaroslav Čermák u župi dubrovačkoj, „Prilozi povijesti umjetnosti u Dalmacji” 1961, vol. 13, nr 1, s. 307-321.

13 I. Długoń, op. cit., s. 94.

14 [J. Czartoryski] G.C., Carl Fichtner. Eine Skizze seines Lebens und künstlerischen Wirkens, Wien 1865. Zob. też: R. Taborski, Działalność kulturalna wiedeńskich Czartoryskich [w:] idem, Wśród wiedeńskich poloników, Kraków 1983, s. 48-51. 
Przypisuje mu się utrzymywanie stałych kontaktów z Hotelem Lambert, można się domyślać, że jeśli to robił, to za pośrednictwem szwagra ${ }^{15}$. Zatem nie tylko pokrewieństwo, ale i wspólne zainteresowania zbliżyły Jerzego Konstantego Czartoryskiego zarówno do Jaroslava, jak i Karela Čermáków.

Warto dodać, że z Czechami łączyły Jerzego Konstantego Czartoryskiego nie tylko związki rodzinne. W 1867 roku nabył on leżący na Śląsku będącym jednym z krajów Korony św. Wacława majątek Toszonowice Dolne (czes. Dolní Tošanovice), pozostał on w rękach Czartoryskiego do 1877 roku. $\mathrm{Z}$ tego powodu miano

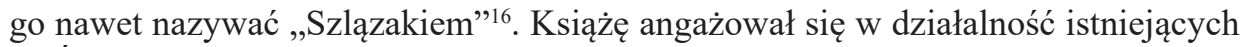
na Śląsku instytucji społecznych i kulturalnych, na przykład wspierał Towarzystwo Rolnicze dla Księstwa Cieszyńskiego, był nawet jednym z jego protektorów. Współpracował także z tamtejszymi działaczami narodowymi i politykami, zwłaszcza polskimi. Dużo lepiej niż większość polityków polskich rozumiał sytuację ludności słowiańskiej zamieszkującej zdominowany przez Niemców Śląsk, tak odmienną od sytuacji Polaków w Galicji. Będąc posłem do Rady Państwa w Wiedniu, angażował się w sprawy ważne dla ludności słowiańskiej na Śląsku, co nie zawsze robili jego koledzy z Koła Polskiego ${ }^{17}$. Można sądzić, że i te doświadczenia powodowały, iż na sprawy monarchii i kwestię współpracy między Słowianami patrzył inaczej niż większość polskich polityków z Galicji.

Na poglądy Jerzego Konstantego Czartoryskiego miało niewątpliwie także wpływ otoczenie, w jakim dorastał. Był najmłodszym synem Konstantego Adama Czartoryskiego, dzieciństwo i młodość spędził w Wiedniu, gdzie w roku jego urodzenia osiadła rodzina. Wychowany w atmosferze stolicy monarchii postrzegany był jako „prawie wiedeńczyk”. Wytykano mu „kosmopolityczne wychowanie”, które „zabiło w nim prawie polskość", obcy akcent czy wręcz nieznajomość języka polskiego, ale

15 J. Klaczko, Kongres v Moskvě a propaganda panslavistů, Vídeň [1868]; J. Zdrada, Zmierzch Czartoryskich, Warszawa 1969, s. 187. Według Václava Žáčka do wydania pracy Juliana Klaczki przyczynili się czeski emigrant Josef Václav Frič, który był jej thumaczem i pracujący w Wiedniu czeski dziennikarz Vratislav K. Šembera, zob. V. Žáč ek, Josef Václav Frič, Praha 1979, s. 246, 368.

16 M. Makowski, Šlechtická sídla na Těšinském Slezsku / Szlacheckie siedziby na Ślasku Cieszyńskim, Cieszyn-Český Těšín 2005, s. 324-325; Nazywanie Jerzego Konstantego Czartoryskiego „Szlązakiem” tłumaczono także faktem, że w młodości spędzał wiele czasu w dobrach rodowych na Śląsku. Owe dobra to zapewne zamek Ruhrber (obecnie Ciszyca w Kowarach) na pruskim Śląsku należący od połowy lat 30. XIX w. do starszego brata księcia Adama Konstantego Czartoryskiego ([S. Rossow ski] Monokl, op. cit., s. 30; Ś.p. Jerzy ks. Czartoryski, „Czas”, 28 XII 1912, nr 597, s. 2-3).

17 J. Zaleski, Dwa jubileusze: Towarzystwa rolniczego dla ks. Cieszyńskiego i Jerzego Cienciaty, Cieszyn 1893, s. 13; A. Grobelný, Slezsko v obdobi národnich táborủ v letech 1868-1871. Trídnĕ politické a kulturně jazykové zápasy českého a polského obyvatelstva v obdobi zvýšených boju o českoněmecké vyrovnání v rakousko-uherské monarchii, Ostrava 1962, s. 47-49, 155-156; I. Ho mola, Ślask Cieszyński w opinii prasy galicyjskiej w latach 1861-1914, „Studia i Materiały z Dziejów Śląska” 1967, t. 8, red. K. Popiołek, s. 189-190, 193-194; S. Pijaj, Mezi Slezskem a Haliči. Jerzy Cienciała jako poslanec do říšsé rady, „Časopis Matice moravské”, R. 129, 2010, č. 1, s. 84-85; J. Gruchała, Koło Polskie w austriackiej Radzie Państwa wobec kwestii czeskiej i Śląska Cieszyńskiego (1879-1899), Wrocław 1982, s. 100-103. 
także zwracano uwagę, że to w okresie wiedeńskim ukształtowały się jego poglądy ${ }^{18}$. Długo nie angażował się bezpośrednio w działalność polityczną, dopiero w okresie powstania styczniowego rozpoczął regularną współpracę z Hotelem Lambert, szybko stając się jednym z najważniejszych współpracowników Władysława Czartoryskiego w Wiedniu. Można jednak sądzić, że już wcześniej wykorzystywano jego kontakty, w 1846 roku dzięki nim nawiązano współpracę ze starowiercami w Moskwie ${ }^{19}$. Zapewne już wtedy był znany w środowiskach Słowian mieszkających w Wiedniu. Było to możliwe dzięki zaangażowaniu Czartoryskich w działalność społeczno-kulturalną tamtejszej wspólnoty słowiańskiej.

Pisząc o wiedeńskim okresie życia Konstantego Adama Czartoryskiego, zwykło się podkreślać jego zainteresowania artystyczne i aktywność na tym polu. Zamiłowania te odziedziczyły jego dzieci, a zwłaszcza najmłodsi synowie Konstanty Marian i Jerzy Konstanty ${ }^{20}$. Jednym z aspektów tej działalności - dotychczas pomijanym było zaangażowanie Czartoryskich w życie kulturalne wspólnoty słowiańskiej w Wiedniu. W latach 40. XIX wieku rozwijało się ono bardzo intensywnie, czego wyrazem były między innymi słowiańskie besedy $\mathrm{i}$ bale. Besedy były spotkaniami towarzyskimi, podczas których odbywały się koncerty i prezentacje utworów literackich, zwłaszcza poezji. Zarówno besedy, jak i bale służyły integracji wiedeńskich Słowian, ale nie tylko, miały także podnieść ich pozycję w oczach miejscowej społeczności. Szczególnego rozmachu nabrały bale słowiańskie organizowane od 1844 roku. Było to możliwe dzięki zaangażowaniu się w nie arystokracji zarówno z monarchii, jak i spoza niej. W latach 40. XIX wieku uczestniczyli w nich i wspierali ich organizację książęta serbscy Miłosz i Milan Obrenoviciowie. Spotkania te z czasem stały się bardzo popularne. Dbano o ich poziom artystyczny, zapraszając czołowych muzyków wiedeńskich, na przykład Johanna Straussa, nie zapominano przy tym o prezentacji kultury Słowian ${ }^{21}$. Polacy byli widoczni zarówno podczas besed, gdzie prezentowano także i polskie utwory, jak i balów, szczególnie Czartoryscy. Wśród gości balu słowiańskiego w 1848 roku wymieniano trzech książąt Czartoryskich, z pewnością mowa o Konstantym Adamie i jego synach. Owo zaangażowanie mogło służyć

18 Biblioteka Naukowa PAU i PAN w Krakowie, rkps 7897: List F. Ziemiałkowskiego do L. Chrzanowskiego z 21 V 1875 r.; K. Chłędowski, Pamiętniki..., t. 2, s. 58; [S. Rossowski] Monokl, op. cit., s. 30; [S. Koźmian], op. cit., s. 28-39; K. Chłędowski, Album fotograficzne..., s. 25. Zapewne dlatego Jerzy K. Czartoryski bardzo dbał, aby jego dzieci wychowywały się w polskiej patriotycznej atmosferze. Zwrócił na to uwagę Leon Sapieha, zob. Muzeum Narodowe w Krakowie (materiały przechowywane w Bibliotece XX. Czartoryskich w Krakowie) (dalej: MNK), rkps 1159: Listy L. Sapiehy do J. Sapieżyny z 22 II 1873 r. i 6 X 1873 r.

19 M. Handelsman, Adam Czartoryski, t. 2, Warszawa 1949, s. 127.

20 R. Taborski, Działalność kulturalna..., s. 46-55; R. Taborski, Polacy w Wiedniu, Wrocław 1992, s. 50-53.

21 Sborník Čechů dolnorakouských, red. J. Karásek, Vídeň 1895, s. 15-39; G. Wytrzens, Die Herausbildung eines Nationalbewußtseins bei den in Wien ansässigen Slaven und die Wiener Slavenpresse [w:] idem, Slawische Literaturen - Österreichische Literatur(en), hrsg. von F.G. Polj kov, S. Simonek, Wien 2009, s. 24-30; M. Glettler, Die Wiener „Slovanská Beseda“ (1865-1914) und Baltazar Bogišić (1865/1866) [w:] Spomenica Valtazara Bogišića o stogodišnjici njegove smrti 24. apr. 2008. godine, ur. L. Breneselović, V. Čolović, J. Ćirić, P. Dimitrijević, J. Trkulja, kn. 1, Beograd 2011, s. 65-66; P. Żurek, Polska i Polacy w życiu Josipa Juraja Strossmayera, Bielsko-Biała 2006, s. 16-17. 
także celom politycznym, nawiązane kontakty ułatwiały działania Hotelowi Lambert wśród Słowian, co było ówcześnie jednym z priorytetów jego polityki. Potwierdza to choćby wspomniana wcześniej pomoc Jerzego Konstantego Czartoryskiego przy poszukiwaniu przez agentów Hotelu Lambert kontaktów ze starowiercami w Moskwie. Warto podkreślić, że to właśnie przy okazji tych wiedeńskich spotkań zapoznali się z koncepcjami Adama Jerzego Czartoryskiego niektórzy słowiańscy politycy 22 .

Po Wiośnie Ludów spotkania te straciły na znaczeniu, co wydaje się zrozumiałe ze względu na sytuację w monarchii. Ożywienie życia słowiańskiego w Wiedniu nastąpiło dopiero pod koniec lat 50. XIX wieku. Podejmowano wtedy także działania na rzecz nadania ram organizacyjnych tej działalności. W początkach 1865 roku grupa osób zaangażowanych w działalność społeczno-kulturalną Słowian powołała w Wiedniu stowarzyszenie „Slovanská Beseda”. Konstanty Marian i Jerzy Konstanty Czartoryscy od początku byli jego członkami, a pierwszy został nawet wybrany do jego władz. W działalność „Slovanskiej Besedy” angażowali się także Karel i Jaroslav Čermákowie. Towarzystwo miało być apolityczne, odgrywać rolę integracyjną i koncentrować się na aktywności kulturalnej, choć - jak się wydaje - nie wszyscy jego członkowie i sympatycy zamierzali się do tego ograniczać. Wśród nich byli przedstawiciele arystokracji, uczeni, duchowni różnych wyznań i urzędnicy ${ }^{23}$. Czartoryscy angażowali się w prace stowarzyszenia do 1868 roku, mimo że część polskiej prasy krytycznie je oceniała. Szczególnie napastliwy był krakowski „Czas”, który oceniał „Slovanską Besedę” jako projekt „panslawistyczny”, przypisał jej polityczne znaczenie i wystąpił z krytyką myśli współpracy politycznej ze Słowianami i to zarówno szukającymi wsparcia w Rosji, jak i w Austrii ${ }^{24}$. Dyskusja na temat „Slovanskiej Besedy” w prasie polskiej pokazuje, jak rozbieżne były opinie wśród Polaków na temat współpracy ze Słowianami. Jerzy Konstanty Czartoryski nie miał oporów, by się w nią angażować, inni taką myśl odrzucali, podkreślając szczególną pozycję Polaków. Towarzystwo „Slovanská Beseda” było próbą kontynuacji współpracy społeczno-kulturalnej Słowian w Wiedniu według dawnej formuły, tworzyli je w większości przedstawiciele elity monarchii (z tego powodu nazywano je „hofratską Besedą”), ale też ludzie spoza niej, w tym Rosjanie. Zaostrzające się w latach 60. XIX wieku w Austrii konflikty

22 Roční zpráva o činnosti představenstva „Slovanské besedý“ roku 1865, Vídeň 1866, 6, 10, 3537; J. Kalanda, Dějiny Slovanske besedy ve Vidni za prvni tř́cetletí jejiho trvani (1865-1894), Vídeň 1895, s. 7-25; G. Wytrzens, Die Herausbildung eines Nationalbewußtseins..., s. 25-26; P. Żurek, op. cit., s. 16-17. Oprócz trzech książąt Czartoryskich wśród uczestników balu słowiańskiego, który odbył się 9 II 1848 r. wymieniano następujących Polaków: Badeniego, Władysława Baworowskiego, Korytowskiego, Ledóchowskiego, Platera, Rzyszczewskiego, zob. Slavjanski bal u Beču, „Danica horvatska, slavonska i dalmatinska", 4 III 1848, nr 10, s. 44.

23 G. Wytrzens, Die Herausbildung eines Nationalbewußtseins..., s. 30-31; M. Glettler, op. cit., s. 66-69; E. Hüttl-Hubert, Anmerkungen zu Bogišić' Beziegungen zu Wien [w:] Spomenica Valtazara Bogišića o stogodišnjici njegove smrti 24. apr. 2008. godine, ur. L. Breneselović, V. Čolović, J. Ćirić, P. Dimitrijević, J. Trkulja, kn. 1, Beograd 2011, s. 100-102. Spośród Polaków w działalność „Slovanskiej Besedy” byli zaangażowani także Jerzy Lubomirski i Artur Grottger, który należał do jej zarządu.

24 „Czas”, 19 X 1865, nr 239, s. 1; 25 X 1865, nr 244, s. 1. Z „Czasem” polemizowało kilka gazet galicyjskich, zob. np.: „Gazeta Narodowa”, 3 XI 1865, nr 251, s. 1; „Hasło”, 1 XI 1865, nr 78, s. 1. 
spowodowały, że taka formuła działania już się wyczerpała. "Slovanská Beseda” funkcjonowała, ale po kilku latach stała się faktycznie czeskim stowarzyszeniem.

Na poglądy Jerzego Konstantego Czartoryskiego dotyczące kwestii współpracy Słowian wpłynęło kilka czynników. Na pierwszym miejscu trzeba niewątpliwie wymienić wpływ środowiska, w którym dorastał i przebywał do połowy lat 60 . XIX wieku. Wychowany w Wiedniu - centrum wielonarodowej monarchii, zaangażowany w życie tamtejszej wspólnoty słowiańskiej, znał Słowian lepiej niż większość Polaków w Galicji. Łatwiej było mu zrozumieć ich dążenia i znaleźć z nimi wspólny język. Jego spojrzenie na sprawy słowiańskie determinowały także doświadczenia ze Śląska, gdzie sytuacja Polaków i Czechów zdominowanych przez Niemców, wśród których coraz silniejsze były tendencje nacjonalistyczne, była trudna i nie zmieniło jej wprowadzenie rządów konstytucyjnych. Dla większości polityków polskich z Galicji była to sprawa drugorzędna i z tego powodu lekceważona. Nie należy pomijać także i wpływu rodziny, która ułatwiała mu wejście w środowiska czeskie. Wydaje się jednak, że jego sympatie do Słowiańszczyzny nie były skutkiem małżeństwa jak utrzymywano, lecz raczej to małżeństwo z Marią Čermák było jednym ze skutków zaangażowania Jerzego Konstantego Czartoryskiego w działalność na rzecz Słowian.

$\mathrm{W}$ połowie lat 60 . XIX wieku nastąpiła istotna zmiana w życiu Jerzego Konstantego Czartoryskiego, związał się mocniej z Galicją i zaangażował szerzej w politykę. Nie oznacza to, że porzucił Wiedeń, nadal był właścicielem tamtejszej rodzinnej rezydencji w Weinhaus, która pozostała miejscem spotkań towarzyskich i politycznych ${ }^{25}$. Nadal także, wespół z rodziną, działał społecznie na terenie Wiednia, jak można sądzić, przede wszystkim na rzecz Polaków ${ }^{26}$.

Zaangażowanie w politykę Jerzego Konstantego Czartoryskiego thumaczy się w różny sposób, najczęściej wskazuje się dogodne okoliczności, jakie zaistniały w tym czasie w monarchii, dające Polakom możliwość realizacji własnych celów politycznych. Warto jednak zwrócić uwagę, że nie tylko on zdecydował się na taki krok, zrobił to również jego brat Konstanty Marian. W Austrii zaczął lokować swe nadzieje także kuzyn Jerzego Konstantego, przywódca Hotelu Lambert Władysław Czartoryski, liczący na podjęcie przez monarchię habsburską sprawy polskiej. Na jego stanowisko wpłynęło między innymi zerwanie przez Wiedeń z polityką centralizacyjną i objęcie rządów latem 1865 roku przez zwolenników federalizmu. W tym okresie Władysław Czartoryski opowiadał się za federalizacją monarchii, niejednokrotnie wypowiadał się na temat konieczności przyznania autonomii narodowościom ją zamieszkującym i uwzględnienia praw Słowian. Jerzy Konstanty Czartoryski, jak i jego brat zaczęli wspierać Władysława na gruncie wiedeńskim, należeli w ciągu następnych kilku lat do grupy jego bliskich współpracowników ${ }^{27}$. Można zatem za-

25 List F.L. Riegla do M. Červinkove-Riegrove z 16 V 1887 r. [w:] [F.L. Rieger], Př́spěvky k listáŕi..., s. 306; K. Chłędowski, Pamiętniki..., t. 2, s. 58-59.

26 W.S. Kucharski, Polacy i Polonia w rdzennej Austrii w XIX i XX wieku, Lublin 1994, s. 63-74; Z. To mkow ski, Polskie Stowarzyszenie Akademickie ,Ognisko” w Wiedniu w latach niewoli narodowej (1864-1914) [w:] Polonia i przyjaciele Polski w Austrii, red. W.S. Kucharski, Lublin 1995, s. 128-129.

27 J. Zdrada, Sprawa autonomii galicyjskiej w polityce Hotelu Lambert w latach 1859-1873, „Studia Historyczne”, R. 10, 1967, z. 3/4, s. 58-71. Szerzej na ten temat zob. J. Zdrada, Zmierzch 
kładać, że to Władysław Czartoryski miał wpływ na ich zaangażowanie się w politykę. Z czasem między kuzynami pojawiły się rozbieżności dotyczące między innymi kwestii słowiańskiej. Rozchodzenie się dróg Jerzego Konstantego i Władysława Czartoryskich następowało stopniowo w okresie walki o realizację postulatów rezolucji galicyjskiego Sejmu Krajowego z września 1868 roku. Ostatecznie przywódca Hotelu Lambert odżegnał się od federalizmu w 1870 roku, podczas wystąpienia z okazji rocznicy ogłoszenia Konstytucji 3 maja skrytykował ideę federalizacji monarchii, odciął się od współpracy ze słowiańską opozycją i zaatakował jej przedstawicieli, szczególnie Czechów ${ }^{28}$. Jerzy Konstanty Czartoryski pozostał konsekwentnym federalistą. W tym czasie stał się przywódcą tego ruchu w Galicji i jednym $\mathrm{z}$ jego liderów w monarchii.

Środowisko określane mianem federalistów było niejednorodne, trzon jego stanowili Słowianie. W parlamencie wiedeńskim tworzyli je: Czesi, Polacy, Słoweńcy, Chorwaci z Istrii i Dalmacji oraz pochodzący stamtąd Serbowie, ponadto część Rumunów z Bukowiny i grupa konserwatystów niemieckich. Pod koniec lat 60. XIX wieku część polityków związanych z obozem federalistów pogodziła się z faktem, że monarchii nie da się już przekształcić w państwo federalne i zaczęła realizować odrębne programy autonomiczne. Najlepszym tego przykładem byli Polacy, którzy widząc możliwość uzyskania specjalnego statusu dla Galicji, skoncentrowali się na działaniach idących w tym kierunku. Własne postulaty sformułowali w latach 1870 i 1871 Słoweńcy; jak się okazało, do kompromisu z władzami w Wiedniu gotowi byli także posłowie z Dalmacji. Konserwatystom niemieckim w pierwszej kolejności chodziło o zablokowanie zmian politycznych i społecznych forsowanych przez centralistycznie nastawionych liberałów, temu miała służyć obrona praw historycznych poszczególnych krajów monarchii. Wierni federalizmowi pozostawali Czesi, którzy domagali się specjalnego statusu dla krajów Korony św. Wacława przypominającego pozycję Węgier po 1867 roku. Między poszczególnymi grupami istniały także różnice co do sposobu działania, Czesi konsekwentnie od 1863 roku bojkotowali obrady parlamentu - Rady Państwa, pozostali zaś w nich uczestniczyli29. Cele, metody i możliwości grup tworzących obóz federalistów były różne. Trzeba było wiele wysiłku, aby je pogodzić. Jerzy Konstanty Czartoryski wykazywał się w tym dużą determinacją, zwłaszcza gdy chodziło o Słowian. Uważał on, że ówcześnie w monarchii rzeczywiście mogły istnieć tylko dwa stronnictwa: federaliści i centraliści, na inne nie było miejsca. W tej sytuacji wybór był oczywisty, należało opowiedzieć się za federalizmem, bo to gwarantowało zabezpieczenie praw wszystkim narodom, a także zbliżało Polaków do Słowian, co było jego zdaniem rzeczą naturalną. Podobnie

Czartoryskich, Warszawa 1969, s. 94 i n. (szczególnie s. 126, 151, 155, 160, 211, 216, 243, 301); S. Pijaj, Parlamentarna działalność Czartoryskich w monarchii habsburskiej [w:] Czartoryscy-PolskaEuropa. Historia i współczesność, red. Z. Baran, Kraków 2003, s. 178-179.

28 J. Zdrada, Sprawa autonomii galicyjskiej..., s. 67-69; idem, Zmierzch Czartoryskich..., s. 346-354; S. Pijaj, Między polskim patriotyzmem a habsburskim lojalizmem. Polacy wobec przemian ustrojowych w monarchii habsburskiej (1866-1871), Kraków 2003, s. 326-327.

29 S. Pijaj, Opozycja w wiedeńskiej Radzie Państwa w latach siedemdziesiatych XIX w. (sktadorganizacja-funkcjonowanie), Kraków 2011, s. 34-40. 
oceniał sytuację w Galicji i wzywał do stworzenia tam szerokiego stronnictwa federalistycznego ${ }^{30}$. Wśród Polaków politycy tak myślący byli jednak w mniejszości.

Działania na rzecz integracji środowiska federalistów ułatwiały Jerzemu Konstantemu Czartoryskiemu kontakty posiadane wśród Słowian, zwłaszcza wśród Czechów. Było to o tyle istotne, że stanowili oni liczącą się siłę, a ich ścisła współpraca z pozostałymi grupami federalistów i powrót do parlamentu dawał szansę na uzyskanie tam przewagi zwolennikom federalizacji monarchii. Jak wspomina jeden z ówczesnych czołowych polityków czeskich František L. Rieger, już w parę tygodni po wyborze na posła do galicyjskiego Sejmu Krajowego, w lutym 1867 roku, Jerzy Konstanty Czartoryski miał uczestniczyć w rozmowach polsko-czeskich w Pradze, dotyczących udziału w obradach Rady Państwa. Wydaje się to jednak mało prawdopodobne, zapewne polityk czeski pomylił go z bratem Konstantym Marianem, który w tym czasie odgrywał dużo większą rolę ${ }^{31}$. Niewątpliwie jednak Jerzy Konstanty Czartoryski był jedną z osób przygotowujących rozmowy polityków czeskich z premierem Alfredem Potockim w kwietniu 1870 roku, których celem było skłonienie ich do powrotu do parlamentu, a przez to wzmocnienie pozycji rządu kierowanego przez Polaka. Ponoć starał się ich „mitygować”32. Stopniowo zyskiwał na znaczeniu, widziano w nim ,naczelnika stronnictwa” federalistów w Galicji ${ }^{33}$. Jako taki uczestniczył w rozmowach i kolejnych spotkaniach, na których próbowano przygotować wspólny program i ustalić zasady współpracy zwolenników federalizmu. To dzięki postawie Czartoryskiego i innych Polaków zakończyła się powodzeniem konferencja w Wiedniu w marcu 1873 roku, zaproponowali oni bowiem formułę działania i program satysfakcjonujący wszystkich. Konsultacje i spotkania nasiliły się po wyborach do Rady Państwa w 1873 roku. Czartoryski deklarował się wtedy jako zdecydowany zwolennik obesłania parlamentu wiedeńskiego, nie ustawał w wysiłkach, aby skłonić do tego Czechów. Apelował o to do polityków czeskich na listopadowej konferencji federalistów w Wiedniu, zwracał się także w tej sprawie bezpośrednio do swych czeskich przyjaciół ${ }^{34}$. Wykorzystując kontakty i swój autorytet, starał się również wpływać na Słoweńców, jesienią 1873 roku odwiedził Lublanę, zachęcał do współpracy i próbował godzić skłóconych polityków słoweńskich ${ }^{35}$. Jego zabiegi nie przyniosły jednak rezultatów, większość Czechów zdecydowała się kontynuować bojkot Rady Państwa, opozycja federalistyczna nie była w stanie się zjednoczyć.

30 J. Czartoryski, Uwagi o polityce polskiej..., s. 8-17, 23-24, 55-61. Zob. też: idem, Przed sejmem..., s. 4-14.

31 F.L. Rieger, Z vlastnich pamětí Fr. Lad. Riegra, „Osvěta”, R. 36, 1906, t. 1-2, s. 576-577; S. Pijaj, Między polskim patriotyzmem a habsburskim lojalizmem ..., s. 132-133; idem, Parlamentarna działalność Czartoryskich..., s. 179-182.

32 MNK, rkps 1158: Listy L. Sapiehy do J. Sapieżyny z 29 IV 1870 r.; S. Pijaj, Między polskim patriotyzmem a habsburskim lojalizmem..., s. 323-324.

33 „Gazeta Narodowa”, 27 XI 1872, nr 325, s. 5.

34 S. Pijaj, Opozycja w wiedeńskiej Radzie Państwa ..., s. 44-46, 119-131.

35 J. Vošnjak, Spomini, t. 2, Ljubljana 1906, s. 253-256; A. Cetnarowicz, Polacy i Stoweńcy w monarchii habsburskiej. Uwagi na temat wzajemnych stosunków w drugiej połowie XIX wieku, „Prace Historyczne" 1997, nr 121: Studia Austro-Polonica 5, s. 215. 
Różnice w obozie federalistów musiały odbić się na ich współpracy w Radzie Państwa, uniemożliwiły powołanie jednego klubu opozycyjnego. Czartoryski miał zbyt słabą pozycję, aby przekonać do tego rodaków. Konserwatyści niemieccy i grupa posłów słowiańskich stworzyli Klub Prawego Centrum, przeważali w nim ci pierwsi. Nie zaangażował się w projekt „klubu słowiańskiego”, o którego powołaniu mówiono na początku 1874 roku. Pomysł ten narodził się wśród posłów słoweńskich, zakładał on współpracę niewielkiej grupy posłów czeskich z Moraw, którzy zdecydowali się na udział w obradach Rady Państwa, pojedynczych posłów południowosłowiańskich, kilkunastu posłów ruskich mających własny klub i wspierających centralistyczny rząd oraz grupy posłów polskich, którzy opuściliby klub polski. Był on nie do przyjęcia nie tylko dla Polaków. Słowianie w Radzie Państwa pozostali podzieleni. Największą grupę wśród nich stanowili Polacy, którzy tradycyjnie stworzyli własny klub nazywany Kołem Polskim, wkrótce okazało się, jak niewielką grupą wśród nich byli federaliści i jak ograniczone mieli możliwości. Skupieni wokół Jerzego Konstantego Czartoryskiego, starali się zabiegać o realizację elementów swego programu i dążyli do zacieśnienia współpracy Koła Polskiego z Klubem Prawego Centrum. Nie zawsze było to łatwe zarówno z powodu pojawiających się między obydwoma klubami rozbieżności, jak i prób prowadzenia utylitarnej polityki. W połowie kadencji frakcja federalistów próbowała skłonić Koło do zajęcia bardziej opozycyjnego stanowiska, zabiegi te nie dały rezultatów. Zniechęcony tym Czartoryski jesienią 1876 r. złożył mandat poselski ${ }^{36}$. Porażka Czartoryskiego wynikała z faktu, że koncepcja federalistycznej przebudowy monarchii była w ówczesnych warunkach niemożliwa do zrealizowania, poza tym okazało się, że środowisko federalistów jest słabe i mocno podzielone. Dotyczyło to również Słowian, silnie zintegrowani Polacy tworzący w Radzie Państwa zdyscyplinowany klub poselski byli ewenementem. Zabiegi Czartoryskiego, aby skłonić do ściślejszej współpracy polityków słowiańskich nie przyniosły skutku.

Jerzy Konstanty Czartoryski wrócił do wiedeńskiej polityki pod koniec lat 70 . XIX wieku. Kryzys centralistycznego rządu i wspierającej go w parlamencie koalicji otworzył nowe perspektywy, zwłaszcza że politycy czescy - dotąd przeciwni udziałowi w obradach Rady Państwa - sygnalizowali gotowość zakończenia bojkotu. Czartoryski szybko na to zareagował, na początku lipca 1878 roku odwiedził Pragę, próbował się zorientować, w jakich okolicznościach Czesi byliby gotowi powrócić do parlamentu ${ }^{37}$. Część polityków galicyjskich uważała, że to właśnie on mógłby być jednym z twórców sojuszu Czechów, Polaków i grup tworzących Klub Prawego Centrum. On sam - jak się zdaje - zastanawiał się, czy ponownie się angażować. Jednym z czynników, który pomógł mu w podjęciu decyzji, była gotowość wejścia Czechów do Rady Państwa. Po wyborach w 1879 roku miał w Kole Polskim dużo silniejszą pozycję niż wcześniej, ubiegał się nawet o jego prezesurę. Deklarował się jako zwolennik ścisłego współdziałania z Czechami i Klubem Prawego Centrum,

36 S. Pijaj, Opozycja w wiedeńskiej Radzie Państwa ..., s. 136-137, 140-141, 150-164.

37 P. Cibulka, Česká politika na řišské radě v prvnich létech Taaffovy vlády a její spojenci (18791885), Brno 1992 (mps pracy doktorskiej), s. 40. 
w którym ponownie znaleźli się posłowie południowosłowiańscy, to między innymi spowodowało, że zaczęto mu zarzucać „kosmopolityzm słowiański”. Jego postulaty nie zostały wprawdzie zaakceptowane, stopniowo jednak - mimo wątpliwości części polskich polityków - zacieśniano więzy między tymi grupami, co doprowadziło do powołania koalicji ,żelaznego pierścienia”. Czartoryski należał do jej architektów ${ }^{38}$. Ten wyjątkowo trwały - jak na austriackie warunki - sojusz, będący stabilnym zapleczem rządu, wzmocnił wpływy federalistów i Słowian w monarchii, nie doprowadziło to jednak do zmian ustrojowych w państwie. Wszelkie koncesje, jakie uzyskiwali w tym czasie Słowianie, nadawano im w ramach obowiązującej konstytucji. Sojusz nie oznaczał także zniknięcia kwestii spornych między jego uczestnikami, taką był na przykład stosunek do Rosji. Wśród posłów polskich zwolennicy współpracy słowiańskiej byli w mniejszości, większość skłaniała się do takiego sojuszu ze względu na kalkulację polityczną. Wśród zwolenników na pierwszym miejscu wymieniano zazwyczaj Jerzego Konstantego Czartoryskiego ${ }^{39}$. Nie można się zatem dziwić, że gdy doszło do rozpadu koalicji należał on do tych członków Koła Polskiego, którzy opowiadali się za jej odbudową i sprzeciwiał się sojuszowi z lewicą niemiecką, czemu sprzyjał rząd. Uznano go za na tyle niebezpiecznego, że zdecydowano się usunąć z Izby Posłów. Zabiegi premiera spowodowały nominowanie Jerzego Konstantego Czartoryskiego członkiem Izby Wyższej austriackiego parlamentu, musiał zrezygnować z mandatu do Izby Niższej ${ }^{40}$. W Izbie Wyższej nie odgrywał już tak istotnej roli politycznej.

Osobną, wartą uwagi kwestią jest stosunek Jerzego Konstantego Czartoryskiego do Rusinów. Czartoryski podkreślał znaczenie kwestii ruskiej w Galicji, uważał ją wręcz za „kwestię życia lub śmierci” dla mieszkających tam Polaków. Był zwolennikiem współpracy polsko-ruskiej. Uznawał odrębność narodową Rusinów, która nie była rzeczą oczywistą dla wszystkich polityków polskich, i deklarował chęć zawarcia z nimi porozumienia. Nie wahał się ostro krytykować przeciwników takiego porozumienia wśród rodaków ${ }^{41}$. Porozumienie miał ułatwić federalizm, przekształcenie państwa w duchu federalnym miało bowiem otworzyć drogę do rozwiązania kwestii ruskiej w Galicji. To właśnie wśród działaczy ruskich sympatyzujących z federalistami szukał Czartoryski partnerów ${ }^{42}$. Porozumienie, którego podstawą miały być sejmowe wnioski ugodowe z 1869 roku, próbowano z powodzeniem realizować na

38 A.O. Zeithammer, Polnisch-böhmische Beziehungen. Fürst Georg Czartoryski. Separatabdruck aus der Zeitschrift „Union” von 23. März 1913, Prag 1913, s. 19; J. Gruchała, op. cit., s. 16-21; W. Łazuga, Kalkulować... Polacy na szczytach C.K. Monarchii, Poznań 2013, s. 110-111.

${ }_{39}$ Zob. np. charakterystykę posłów polskich autorstwa córki F.L. Riegra M. Červinkovej-Riegrovej: M. Červinková-Riegrová, Zápisky. II (1885-1886), Praha 2013, s. 315; J. Gruchała, op. cit., s. $25-26$.

40 List E. Taaffe do K. Badeniego z 1 IV 1891 r. [w:] Der politische Nachlaßes Grafem Eduard Taaffe, hrsg. von A. Skedl, Wien 1922, s. 286; J. Gruchała, op. cit., s. 41.

${ }_{41}$ J. Czartoryski, Przed sejmem..., s. 3; J. Czartoryski, Uwagi o polityce polskiej..., s. 6-7, $38,51-54$.

42 S. Pijaj, Działalność Jerzego Czartoryskiego i Stefana Kaczaly na rzecz zawarcia ugody polsko-ukraińskiej w Galicji w latach siedemdziesiątych XIX wieku [w:] Galicja. Studia z dziejów społeczno-gospodarczych, red. M. Baczkowski, T. Kargol, Kraków 2017, s. 164-167. 
szczeblu lokalnym przed wyborami do Rady Państwa w 1873 roku. Nie wpłynęło to jednak na wynik wyborów, wspólni polsko-ruscy kandydaci ponieśli klęskę. Dzięki wsparciu Czartoryskiego w Radzie Państwa znalazł się jedynie przywódca federalistów ruskich ksiądz Stefan Kaczała, który wstąpił do Koła Polskiego ${ }^{43}$. Kontynuacją działań podjętych przez środowisko polityczne bliskie Czartoryskiemu było złożenie w 1875 roku przez Ignacego Kamińskiego w Sejmie Krajowym kolejnego wniosku ugodowego. Jego autorstwo prasa przypisywała Czartoryskiemu, jednak nie było to prawdą. Nad wnioskiem nie podjęto prac w sejmie, co między innymi przyczyniło się do fiaska planów ugody i rozpadu środowiska jej zwolenników skupionych wokół księcia ${ }^{44}$.

Do idei wyborczego porozumienia z Rusinami powrócił Czartoryski przed wyborami do Rady Państwa w 1879 roku. Jako prezes polskiego Centralnego Komitetu Wyborczego dla wschodniej Galicji działał na rzecz umieszczenia na listach kandydatów na posłów ruskich działaczy narodowych młodszego pokolenia i tym razem przyniosło to niewielkie efekty. $\mathrm{Z}$ tego powodu wypominano mu „zbyteczną chęć miłej zgody"45. W Sejmie Krajowym nadal jednak popierał ideę ugody. Starał się działać na rzecz realizacji wniosków korzystnych dla Rusinów, widać to zwłaszcza w latach 80. XIX wieku, gdy regularnie wspierał działania posłów ruskich na rzecz rozwoju szkolnictwa narodowego ${ }^{46}$. Przypisywano mu także chęć finansowania ruskich wydawnictw i instytucji oświatowych, co miało być częścią porozumienia, któremu patronowali Józef Ignacy Kraszewski i Pantełejmon Kulisz, można mieć jednak wątpliwości, czy to prawda ${ }^{47}$. W latach 90. XIX wieku nie odgrywał już tak istotnej roli w działaniach na rzecz zawarcia ugody polsko-ukraińskiej, nadal jednak zaliczany był do grupy polityków polskich w Galicji, którzy mieli najwięcej zrozumienia dla problemów ludności ruskiej, co przekładało się na jego działania na szczeblu lokalnym. Rozczarowany radykalizacją nastrojów w Galicji na początku XX wieku pisał do greckokatolickiego biskupa przemyskiego Konstantego Czechowicza:

43 М. Мудрий, Спроби украӥнсько-польського порозуміння в Галичині (60-70-i роки XIX cm.), „Україна. Культурна спадщина, національна свідомість, державність” 1997, вип. 3-4, s. 101-102; M. Semczyszyn, Galicyjskie wybory. Działalność Centralnego Komitetu Wyborczego w Galicji Wschodniej w latach 1867-1906, Warszawa 2014, s. 280-283; S. Pijaj, Działalność Jerzego Czartoryskiego..., s. 167-171, 176. Jerzy Konstanty Czartoryski zabiegał także, aby Koło Polskie w Radzie Państwa nazywano „kołem polsko-ruskim”. Zob. S. Pijaj, Opozycja w wiedeńskiej Radzie Państwa..., s. 158.

44 S. Pijaj, Działalność Jerzego Czartoryskiego..., s. 173-176; I. Чорновол, Українська фракиія Галицького крайового сейму 1861-1901 (нарис з історії украӥнського парламентаризму), Львів 2002, s. 156-160.

45 [S. Koźmian], Reprezentacja kraju naszego..., s. 32; M. Semczyszyn, op. cit., s. $287-291$.

46 J. Moklak, W walce o tożsamość Ukraińców. Zagadnienie języka wykładowego w szkołach ludowych i średnich w pracach galicyjskiego Sejmu Krajowego 1866-1892, Kraków 2004, s. 159-160, 172, 175-176, 183, 186, 206, 210; І. Чорновол, Украӥнська фракиія..., s. 173, 177-179, 188.

47 S. Kieniewicz, Adam Sapieha 1828-1903, Warszawa 1993, s. 379-381; E. Hornowa, Pertraktacje Kraszewskiego i Kulisza w sprawie zbliżenia polsko-ukraińskiego (Fragment z dziejów stosunków polsko-ukraińskich w Galicji w latach osiemdziesiątych XIX w.), „Zeszyty Naukowe Wyższej Szkoły Pedagogicznej w Opolu. Historia” 1967, z. 6, s. 228-229; I. Чорновол, Польсько-украӥнська угода 1890-1894 рр., Львів 2000, s. 74-78. 
[...] od trzydziestu kilku lat mojego działania politycznego przy każdej sposobności występowałem zawsze - nieraz wbrew zdaniu rodaków moich - w obronie praw ruskiego narodu, popierając niejedno jego żądanie, przemawiając zawsze za zgodą między obiema narodowościami, sam postępując niezachwianie w tym kierunku w sprawach powiatowych, gminnych, szkolnych itp. ${ }^{48}$

Poglądy polityczne Jerzego Konstantego Czartoryskiego trudno precyzyjnie określić, współcześni mu także mieli z tym kłopoty. Postrzegano go zarówno jako demokratę, konserwatystę, jak i liberała, on sam uważał się za tego ostatniego. W początkach kariery należał do Klubu Rezolucjonistów, następnie przewodził federalistom, później był jednym z przywódców grupy umiarkowanych konserwatystów z Galicji Wschodniej nazywanej „Ateńczykami” i sejmowego klubu Centrum, ale najdłużej był zapewne posłem niezależnym. Te sprzeczności w ocenie Czartoryskiego tłumaczy federalizm, któremu pozostał wierny. Jako federalista nie miał oporów przed współpracą zarówno z demokratami, jak i konserwatystami, o ile zgadzał się z nimi w kwestii organizacji monarchii ${ }^{49}$. Był także zwolennikiem współpracy Słowian, co w naturalny sposób udawało się godzić z federalizmem. Jednym ze źródeł owych sympatii słowiańskich Czartoryskiego były jego doświadczenia wiedeńskie, które pozwalały szerzej spojrzeć na problemy Słowian austriackich i problemy całej monarchii. Stąd Czartoryski, angażując się w politykę, nie koncentrował się jedynie na kwestiach ważnych dla Polaków w Galicji, uwzględniał także interesy innych narodowości, zwłaszcza Słowian, z którymi współpracę uważał za niezwykle istotną, także z powodu rosnącego nacjonalizmu niemieckiego. Nie znajdował zrozumienia dla swych koncepcji wśród rodaków w Galicji, gdzie przewagę zyskali zwolennicy polityki utylitarnej, bardzo skutecznej, ale i bardzo prowincjonalnej, skoncentrowanej na problemach Polaków w Galicji, biernej nie tylko wobec problemów Słowian w monarchii habsburskiej, ale i rodaków żyjących poza tą prowincją, choćby na Śląsku Cieszyńskim ${ }^{50}$.

48 List J.K. Czartoryskiego do bp. K. Czechowicza z 18 XI 1906 r. [w:] Konstanty Czechowicz. Korespondencja greckokatolickiego biskupa przemyskiego z lat 1897-1914, wyd. A. Krochmal, Przemyśl 1998, s. 66; zob. też List J.K. Czartoryskiego do bp. Czechowicza z 22 II 1911 r. [w:] ibidem, s. 104.

49 W połowie lat 70. XIX w. J.K. Czartoryski pisał do wyborców: „[...] w Austrii stronnictwa faktycznie nie dzielą się według oklepanych formułek doktrynerstwa parlamentarnego, lecz według zasad tyczących się stosunków prawno-państwowych, tyczących się ukonstytuowania monarchii. Widzieliśmy nieraz jak frakcje okrzyczane jako reakcyjne walczyły za wolnością i samorządem, z drugiej zaś strony doświadczyliśmy aż nadto, jak daleko stronnictwo centralistyczno-ministerialne podporządkowuje sprawy wolności swoim celom centralistycznym i germanizacyjnym, przede wszystkim zaś swojemu głównemu celowi: utrzymaniu się przy władzy”. J. Czartoryski, Do Szanownych wyborców okręgu Bocheńsko-Brzesko-Wielickiego (na ręce. W. p. Erazma Niedzielskiego), „Czas”, 20 X 1876, nr 240, s. 3.

50 J. Gruchała, op. cit.; S. Pijaj, Sprawy szkolne na Ślasku austriackim w polityce Koła Polskiego $w$ wiedeńskiej Radzie Państwa V kadencji [w:] Amico, socio et viro docto. Księga ku czci profesora Andrzeja Kazimierza Banacha, red. T. Pudłocki, K. Stopka, Kraków 2015, s. 231-241. 


\section{BIBLIOGRAFIA}

\section{Źródła}

Źródta rękopiśmienne

Biblioteka Naukowa PAU i PAN w Krakowie rkps 7897: Korespondencja Leona Chrzanowskiego z lat 1872-1894.

Biblioteka XX. Czartoryskich w Krakowie rkps 7636 III: W. Dzieduszycki, Wiązownica dom moich Dziadków (mps).

Muzeum Narodowe w Krakowie (materiały przechowywane w Bibliotece XX. Czartoryskich w Krakowie)

rkps 1158: Archiwum Sapiehów. Korespondencja Jadwigi z Zamojskich Sapieżyny. Listy od męża Leona Sapiehy z lat 1865-1870.

rkps 1159: Archiwum Sapiehów. Korespondencja Jadwigi z Zamojskich Sapieżyny. Listy od męża Leona Sapiehy z lat 1871-1877.

Źródła drukowane

Chłędowski K., Album fotograficzne, oprac. i wyd. A. Knot, Wrocław 1951.

Chłędowski K., Pamiętniki, przyg. do druku, wstęp i przyp. A. Knot, t. 1: Galicja (18431880), Wrocław 1951, s. 297; t. 2: Wiedeń (1881-1901), Wrocław 1951.

[Czartoryski J.] G.C., Carl Fichtner. Eine Skizze seines Lebens und künstlerischen Wirkens, Wien 1865.

Czartoryski J., Przed sejmem 1869, Lwów 1869.

Czartoryski J., Uwagi o polityce polskiej w Austryi, Lwów 1871.

Konstanty Czechowicz. Korespondencja greckokatolickiego biskupa przemyskiego z lat 1897-1914, wyd. A. Krochmal, Przemyśl 1998.

Červinková-Riegrová M., Zápisky. I (1880-1884), Praha 2009.

Červinková-Riegrová M., Zápisky. II (1885-1886), Praha 2013.

Klaczko J., Kongres v Moskvě a propaganda panslavistů, Vídeň [1868].

[Koźmian S.], Reprezentacja kraju naszego w Radzie Państwa 1879, Kraków 1879.

Der politische Nachlaßes Grafem Eduard Taaffe, hrsg. von A. Skedl, Wien 1922.

[Rieger F.L.], Přispěvky k listáři Dra Frant. Lad. Riegra, díl 1-2, Praha 1924.

Rieger F.L., Z vlastnich pamětí Fr. Lad. Riegra, „Osvěta”, R. 36, 1906, t. 1-2, s. 207-218, 302-313, 395-402, 575-586.

Roční zpráva o činnosti predstavenstva „Slovanské besedy”” roku 1865, Vídeň 1866.

[Rossowski S.] Monokl, Wizerunki sejmowe. Ludzie i sprawy. Przyczynek do historyi samorządu galicyjskiego, Lwów 1903.

Sapieżyna M., My i nasze Siedliska, Kraków 2008.

Vošnjak J., Spomini, t. 2, Ljubljana 1906.

Zaleski J., Dwa jubileusze: Towarzystwa rolniczego dla ks. Cieszyńskiego i Jerzego Cienciaty, Cieszyn 1893. 
Prasa

„Czas” 1865, 1876, 1912.

„Danica horvatska, slavonska i dalmatinska” 1848.

„Gazeta Narodowa” 1865.

„Hasło” 1865, 1872.

„Tygodnik Ilustrowany” 1906.

\section{Opracowania}

Cetnarowicz A., Polacy i Stoweńcy $w$ monarchii habsburskiej. Uwagi na temat wzajemnych stosunków w drugiej połowie XIX wieku, ,Prace Historyczne” 1997, nr 121: Studia Austro-Polonica 5, s. 203-220.

Cibulka P., Česká politika na ř̌̌šké radě v prvních létech Taaffovy vlády a její spojenci (1879-1885), Brno 1992 (mps pracy doktorskiej).

Czartoryscy. Trzydzieści sześć życiorysów, Kraków 1938.

Černý V., Mokrý F.V., Náprstek V., Život a dílo Jaroslava Čermáka, Praha 1930.

Długoń I., Czartoryscy z Pełkiń. Dzieje rodziny, Rzeszów 2019 (mps pracy doktorskiej).

Glettler M., Die Wiener ,, Slovanská Beseda”"(1865-1914) und Baltazar Bogišić (1865/1866) [w:] Spomenica Valtazara Bogišića o stogodišnjici njegove smrti 24. apr. 2008. godine, ur. L. Breneselović, V. Čolović, J. Ćirić, P. Dimitrijević, J. Trkulja, kn. 1, Beograd 2011, s. 65-70.

Grobelný A., Slezsko v obdobi národnich tábori̊ v letech 1868-1871. Třidně politické a kulturně jazykové zápasy českého a polského obyvatelstva v obdobi zvýšených boju o česko-německé vyrovnáni v rakousko-uherské monarchii, Ostrava 1962;

Gruchała J., Koło Polskie w austriackiej Radzie Państwa wobec kwestii czeskiej i Ślaska Cieszyńskiego (1879-1899), Wrocław 1982.

Handelsman M., Adam Czartoryski, t. 2, Warszawa 1949.

Homola I., Śląsk Cieszyński w opinii prasy galicyjskiej w latach 1861-1914, „Studia i Materiały z Dziejów Śląska" 1967, t. 8, red. K. Popiołek, s. 157-295.

Hornowa E., Pertraktacje Kraszewskiego i Kulisza w sprawie zblizenia polsko-ukraińskiego (Fragment z dziejów stosunków polsko-ukraińskich w Galicji w latach osiemdziesiątych $X I X$ w.), „Zeszyty Naukowe Wyższej Szkoły Pedagogicznej w Opolu. Historia” 1967, z. 6, s. 223-231.

Hüttl-Hubert E., Anmerkungen zu Bogišić'Beziegungen zu Wien [w:] Spomenica Valtazara Bogišića o stogodišnjici njegove smrti 24. apr. 2008. godine, ur. L. Breneselović, V. Čolović, J. Ćirić, P. Dimitrijević, J. Trkulja, kn. 1, Beograd 2011, s. 81-121.

Kalanda J., Dějiny Slovanske besedy ve Vidni za prvni tř́cetletí jejiho trvaní (1865-1894), Vídeň 1895.

Kieniewicz S., Adam Sapieha 1828-1903, Warszawa 1993.

Kieniewicz S., Jerzy Konstanty Czartoryski (1828-1912) [w:] Polski słownik biograficzny, t. 4, Kraków 1938, s. 278-279.

Kucharski W.S., Polacy i Polonia w rdzennej Austrii w XIX i XX wieku, Lublin 1994.

Łazuga W., Kalkulować... Polacy na szczytach C.K. Monarchii, Poznań 2013.

Macan T., Jaroslav Čermák u župi dubrovačkoj, „Prilozi povijesti umjetnosti u Dalmacji” 1961, vol. 13, nr 1, s. 307-321.

Makow ski M., Šlechtická sídla na Těšinském Slezsku / Szlacheckie siedziby na Śląsku Cieszyńskim, Cieszyn-Český Těšín 2005. 
Moklak J., W walce o tożsamość Ukraińców. Zagadnienie języka wykładowego w szkotach ludowych i średnich w pracach galicyjskiego Sejmu Krajowego 1866-1892, Kraków 2004.

Pijaj S., Działalność Jerzego Czartoryskiego i Stefana Kaczały na rzecz zawarcia ugody polsko-ukraińskiej w Galicji w latach siedemdziesiatych XIX wieku [w:] Galicja. Studia $z$ dziejów społeczno-gospodarczych, red. M. Baczkowski, T. Kargol, Kraków 2017, s. 161-180.

Pijaj S., Między polskim patriotyzmem a habsburskim lojalizmem. Polacy wobec przemian ustrojowych w monarchii habsburskiej (1866-1871), Kraków 2003.

Pijaj S., Mezi Slezskem a Haliči. Jerzy Cienciała jako poslanec do ř̌̌šsé rady, „Časopis Matice moravské", R. 129, 2010, č. 1, s. 79-98.

Pijaj S., Opozycja w wiedeńskiej Radzie Państwa w latach siedemdziesiatych XIX w. (sktadorganizacja-funkcjonowanie), Kraków 2011.

Pijaj S., Parlamentarna działalność Czartoryskich w monarchii habsburskiej [w:] Czartoryscy - Polska - Europa. Historia i współczesność, red. Z. Baran, Kraków 2003, s. $177-186$.

Pijaj S., Sprawy szkolne na Ślasku austriackim w polityce Koła Polskiego $w$ wiedeńskiej Radzie Państwa V kadencji [w:] Amico, socio et viro docto. Księga ku czci profesora Andrzeja Kazimierza Banacha, red. T. Pudłocki, K. Stopka, Kraków 2015, s. 231-241.

Sborník Čechů dolnorakouských, red. J. Karásek, Vídeň 1895.

Semczyszyn M., Galicyjskie wybory. Działalność Centralnego Komitetu Wyborczego w Galicji Wschodniej w latach 1867-1906, Warszawa 2014.

Šístek F., Zpřitomněna minulost. Jaroslav Čermák: mezi slovanstvím a orientalismem [w:] F. Šístek, Junáci, horalé a lenoši. Obraz Černé Hory a Černohorců v české společnosti, 1830-2006, Praha 2011, s. 52-64.

Taborski R., Działalność kulturalna wiedeńskich Czartoryskich [w:] R. Taborski, Wśród wiedeńskich poloników, Kraków 1983.

Taborski R., Polacy w Wiedniu, Wrocław 1992.

Tomkowski Z., Polskie Stowarzyszenie Akademickie „Ognisko” w Wiedniu w latach niewoli narodowej (1864-1914) [w:] Polonia i przyjaciele Polski w Austrii, red. W.S. Kucharski, Lublin 1995, s. 128-129.

Wytrzens G., Die Herausbildung eines Nationalbewußtseins bei den in Wien ansässigen Slaven und die Wiener Slavenpresse [w:] G. Wytrzens, Slawische Literaturen - Österreichische Literatur(en), hrsg. von F.G. Poljkov, S. Simonek, Wien 2009, s. 24-30.

Zdrada J., Sprawa autonomii galicyjskiej w polityce Hotelu Lambert w latach 1859-1873, „Studia Historyczne”, R. 10, 1967, z. 3/4, s. 43-72.

Zdrada J., Zmierzch Czartoryskich, Warszawa 1969.

Zeithammer A.O., Polnisch-böhmische Beziehungen. Fürst Georg Czartoryski. Separatabdruck aus der Zeitschrift „Union” von 23. März 1913, Prag 1913.

Żurek P., Polska i Polacy w życiu Josipa Juraja Strossmayera, Bielsko-Biała 2006.

Žáček V., Josef Václav Frič, Praha 1979.

Žáček V., S Jaroslavem Čermákem na Černé Hoře a v Albanii, „Slovanský přehled”, R. 68, 1982, č. 4, s. 345-352.

Мудрий М., Спроби українсько-польського порозуміння в Галичині (60-70-і роки XIX cm.), „Україна. Культурна спадщина, національна свідомість, державність” 1997, вип. 3-4, s. 58-117.

Чорновол І., Польсько-українська угода 1890-1894 рр., Львів 2000.

Чорновол I., Украӥнська фракція Галицького крайового сейму 1861-1901 (нарис з історії українського парламентаризму), Львів 2002. 